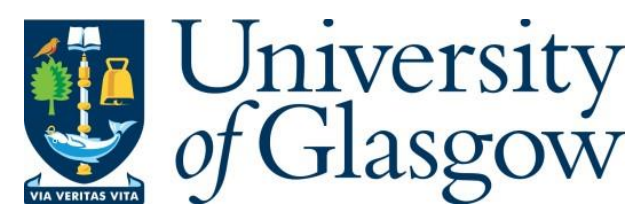

Chiru, M. and Gherghina, S. (2017) Committee chair selection under high informational and organizational constraints. Party Politics, (doi:10.1177/1354068817741765).

There may be differences between this version and the published version. You are advised to consult the publisher's version if you wish to cite from it.

http://eprints.gla.ac.uk/152455/

Deposited on: 15 December 2017

Enlighten - Research publications by members of the University of Glasgow

http://eprints.gla.ac.uk 


\title{
COMMITTEE CHAIR SELECTION UNDER HIGH INFORMATIONAL AND ORGANIZATIONAL CONSTRAINTS
}

\author{
Mihail Chiru \\ Department of Political Science \\ Catholic University of Louvain \\ Sergiu Gherghina \\ Department of Politics \\ University of Glasgow
}

\begin{abstract}
This article draws on major theories of committee organization to explain committee chair selection in contexts with high informational and organizational constraints. We test our theoretical expectations through a series of fixed effects conditional logit models ran on an original dataset which includes all legislators who have served in the Romanian Chamber of Deputies from 1992 to 2012. The findings indicate that sector knowledge matters more for committee chair selection in the first post-communist terms, while chair seniority and party credentials acquire relevance later on. The effect of sector knowledge is stronger than that of chair seniority for the committees that MPs perceive to be the most important, while party leaders have privileged access to the chair position irrespective of how salient the committee is.
\end{abstract}

Keywords: parliamentary committees, chair selection, party organization, Romania.

\section{Introduction}

The composition and functioning of parliamentary committees in European democracies has been extensively studied in the literature, with most research focusing on the formal rules of selection, the absence of official seniority requirements (Mattson and Strøm 1995; Strøm 1998; Yläoutinen and Hallerberg 2012) and the allocation of committee chairs between parties with emphasis on the factors which affect a proportional allocation or strategic use for shadowing purposes (Carroll and Cox 2012). However, little is known about the empirical patterns driving the selection of committee chairs in Europe. More specifically, it remains unclear whether the professional traits of members of parliament (MPs) facilitate their access to the highest committee office. This question gets even more challenging in new democracies where the committee chair selection takes place under three specific informational and organizational constraints (Olson and Crowther 2002). These constraints are: limited parliamentary expertise to be mobilized, ideologically fuzzy parliamentary parties which are also more prone to splits or hopping, and high electoral volatility, which is likely to make calculations on individual electoral gains from committee assignment irrelevant (Mansfeldova et al 2004; Ciftci et al 2008; Heller 
and Mershon 2009; Gherghina 2014). In such a context where political parties are the main actors, the main expectation is that committee chair allocation would follow partisan preferences and make strategic use of the MPs' traits.

This article tests whether this is indeed the case and argues that three particular individual features may influence the likelihood of committee chair selection in a postcommunist democracy. Thus, it aims to identify the extent to which the MPs' sector knowledge, legislative experience and party credentials have an effect on the selection of committee chairs. The analysis is conducted longitudinally to observe whether the three effects change over time with the increase in parliamentary professionalization. In doing so, the article measures for the first time the level of parliamentary policy specialization in a young democracy, but also provides the first investigation of the determinants of committee chair selection in a European context. The only study on the topic outside the United States focused on the Brazilian Congress (Santos and Renno 2004). We build on the major committee organization theories the distributive, the informational and the partisan approach - and use a unique dataset which includes all the politicians who have served in the Romanian Chamber of Deputies from 1992 to 2012. The matched longitudinal data allows us to measure not only the impact of general committee leadership experience but also the effect of parliamentary policy specialization via membership and office in the same committee in the past. The Romanian case is the appropriate setting to test such effects for two reasons. First, it is illustrative for the high informational and organizational constraints which occur in new democracies. Political parties hold the upper hand in office allocation within Parliament, while individual electoral incentives play little role due to the high MP turnover rates. Nevertheless, like in other post-communist Parliaments (Chiru 2010), in Romania there is a remarkable continuity at the level of committee membership and committee office, despite frequent party switching and individual turnover rates. Second, Romanian political parties have also developed extensive clientelistic networks and they are much more interested in office and votes than in policy objectives (Gherghina and Chiru 2013). Given all these elements, Romania represents a hard case among new democracies to test the role of $\mathrm{MPs}^{\prime}$ individual features (related to their professional record and parliamentary expertise) for obtaining a committee chair.

The remainder of this article proceeds as follows. The first section reviews the major theories on committee organization and formulates several testable hypotheses about committee chair selection. Next, we evaluate the main powers and structural attributes of parliamentary committees in Romania and describe the formal rules which govern the selection of committee chairs. The third section describes the research design with emphasis on data, variable operationalization and method. The fourth section presents the multivariate statistical analyses that look both at the longitudinal evolution of committee chair selection and at the recruitment for the most important committees. The conclusions discuss the implications of the results and possible further directions of research.

\section{Drivers of committee chair selection}

The main scope of the theories of committee organization concerns the formation of committees and the assignment of members in committees (Groseclose and King 2001). Due to their origin and focus on the peculiar institutional setting of the US Congress, some of their assumptions and findings do not travel too well even though this limitation applies more to 
some theories - particularly the distributive perspective - than to others. Nevertheless, these theories have empirical implications for the selection of committee chairs, which can be tested on a matched longitudinal sample such as ours. Consequently, the framework below is informed by the theories of committee organization in the attempt to create an explanatory model for committee chair selection. We bring together many of the usual suspects emphasized in the literature to test their explanatory power in contexts in which parties and legislators face high informational and organizational constraints. These constraints take the shape of limited parliamentary expertise, ideological fuzziness and organizational instability of parliamentary parties, and highly volatile electorate that make individual electoral calculations unreliable. Under these circumstances, we argue that three major determinants are likely to influence the committee chair selection: sector knowledge, relevant legislative experience and the party credentials of the MP.

To begin with, all three theoretical perspectives adapted from congressional theories to the specific context of parliaments with informational and organizational constraints emphasize the role of sector expertise for committee chair nominations (H1). According to the informational perspective of committee organization the parliamentary majority should be interested in using efficiently the expertise of its members by nominating them in committees which allow further specialization in the policy area in which they already have experience (Krehbiel 1992). Different empirical analyses emphasized the merits of this perspective. On the one hand, sector knowledge influences the committee assignment in legislatures as different as the European Parliament and Ireland (McElroy 2006; Hansen 2011: 357). On the other hand, academic training or a professional career in the policy field covered by the committee turned out to be a major predictor of committee chair selection in Brazil (Santos and Renno 2004: 65). The partisan perspective would also suggest that sector knowledge is an important precondition for nominating committee chairs. This is so because by nominating someone without sector knowledge as a chair, parties run the risk of seeing their preferred policy outcomes diverted by more knowledgeable legislators from other parties, or by their own party members with more radical views, in a process similar to the potential policy drift of nonspecialist ministers faced with experienced bureaucrats. Thus, it is crucial for parties to select committee chairs who embody the right balance between political skill and expertise, a criterion which was also heavily emphasized by the literature on the selection of ministers (De Winter 1991; Dowding and Dumont 2009).

The distributive theory entails that the committee members are 'high demanders' and they would be ideological outliers compared to the median party member (Weingast and Marshall 1988; Groseclose and King 2001). While this perspective explains that structures in Parliament exist to support the electoral needs of MPs, the political reality is somewhat different. In many new European democracies political parties dominate the entire process of nominations. The high levels of electoral volatility and rates of MP turnover (Chiru 2010; Gherghina 2014) place calculations regarding individual electoral gains on a secondary position when offices are allocated. Consequently, the engagement in distributive politics of the legislators is fairly limited and is replaced by a more institutional logic aimed at consolidating the position of the party. Accordingly, the abilities that recommend the nomination of committee chairs are not unequivocally linked to the MPs' skills in directing benefits to their constituents. Instead, political parties may be inclined to nominate those representatives who 
have sector knowledge and can boost the party's image and policy success. Knowledgeable chairs are thus better able to convey an image of professionalism and play an active role in shaping policies which would eventually increase the party's electoral appeal and only indirectly their own re-election chances.

The second main effect is driven by the legislative experience of the MPs. A major role in this respect is played by committee seniority, the salience of which has been emphasized by both the distributive and the informational theories. However, the distributive theory of committee organization is the least suited to explain committee chair selection in a context with a weak electoral connection, where re-election depends mainly on the party leadership decisions regarding placement on the party list, and where parties control the distribution of parliamentary office. This is the case because the theory maintains that legislators are mainly motivated by re-election concerns and they self-select into the committees that enable them to obtain particularistic benefits for their constituency, such as pork barrel projects (Weingast and Marshall 1988; Groseclose and King 2001), or to those committees that have policy jurisdiction over issues which are of great interest to their constituents. Although in Europe the parties control committee assignment and chair selection, and seniority is nowhere formally institutionalized as a precondition for committee office, it is safe to assume that committee seniority still plays a role in the process.

For most of the last half a century, seniority was all that matter for committee chair selection in the US Congress. The chair would always be the longest (continuously) serving member of the committee (Deering and Wahlbeck 2006: 229). Even in contexts like the European Parliament, in which seniority is not institutionalized, previous membership in a committee is a strong predictor of committee assignment (McElroy 2006). Although other scholars treat it is as a form of 'inertia in committee chair selection' (Santos and Renno 2004: 61), a type of serial correlation that needs to be controlled for, we believe this phenomenon has a substantive meaning which is in line with the predictions of the informational theory. Thus, if the legislative majority is interested in cultivating policy specialization it should favor MPs who served in that committee in the past and even more so, MPs who were chairs of that committee, when selecting legislators for committee leadership positions.

In light of these arguments, we distinguish between five components of parliamentary experience. Starting with the three most specific variables, which imply the highest level of policy specialization, a chair position in the same committee in the past $(\mathrm{H} 2 \mathrm{a})$, experience as a member in that committee $(\mathrm{H} 2 \mathrm{~b})$ or experience as a deputy chair or secretary of the same committee in the past $(\mathrm{H} 2 \mathrm{c})$ are likely to foster nomination as committee chair. At a more general level, just holding committee office in the previous term (irrespective of committee) can positively influence the selection as committee chair $(\mathrm{H} 2 \mathrm{~d})$ because of the experience acquired in leading committee sessions, manipulating the committee agenda, or negotiating with the leadership of the Chamber. At the most general level of experience, a long MP career (H2e) may positively impact the selection as committee chair, given that veteran MPs generally have more knowledge of the legislative process and can rely on a network of connections in other parties which could be instrumental in forging deals in the committees.

The third main effect highlights the salience of party credentials for a committee chair position, namely a high profile of the MPs in the party. According to the partisan theory, parties act as 'legislative cartels', which use the committee system to discipline their members and 
achieve their policy goals (Cox and McCubbins 1993). From this perspective, allocating the committee offices to party leaders is a rational strategy for parties that want 'to monitor the cooperation and compliance' of their members in committees (Ciftci et al 2008) and to maximize their policy influence. Party leaders would also be more reliable in using the negative agenda power enjoyed by committee chairs to delay or block bills detrimental to the party or, conversely to make use of positive agenda power to promote the bills favored by the party (Cox and McCubbins 2005). The appointment of party leaders is even more likely in situations of coalition governments in which parties use committee chairs to keep tabs on the ministers of their coalition partners (Carroll and Cox 2012). This is so because national party leaders are potentially more informed with respect to the issues that divide the coalition. Last but not least, we have to take into account individual motivation: party leaders may exploit their power to reserve for themselves the most desirable committee seats the party is entitled to (Yordanova 2009: 265) and further use them as a stepping stone for a ministerial career or for increasing their policy influence.

H1: Sector knowledge increases the likelihood of being selected committee chair.

H2: Chair seniority (H2a), committee seniority (H2b), committee office seniority (2c), chair positions in other committees $(\mathrm{H} 2 \mathrm{~d})$ and a long parliamentary career $(\mathrm{H} 2 e)$ increase the likelihood of being selected committee chair.

H3: Party leaders are more likely to be selected committee chairs.

The reasoning behind some of these effects is not particular to new democracies and are widely applicable to a broader range of countries. However, the expectations about the longitudinal variation of these effects bring relevant details to the broader picture. New democracies faced several transformations and phases from their regime change to the current situation. These phases include transition to democracy, acquiring a democratic status, consolidation of democracy and sometimes backsliding (e.g. as it is the case with Hungary nowadays). The intensity of effects is closely linked to these phases. We would expect sector knowledge (H1) to be a key determinant of committee chair selection particularly during transition years for at least two reasons. First, one relevant feature of the legislatures in those periods is the absence of past parliamentary policy specialization due to the massive turnover and the different nature of parliamentary politics in authoritarian regimes (i.e. their rubber stamp character). Second, the informational needs of the legislature are more pressing because of the lack of staff and institutional resources (Ostrow 2002: 201; Ilonszki 1995: 198; Roper and Crowther 1998: 420).

At a later phase, when these features fade away or become less predominant, the role of seniority $(\mathrm{H} 2)$ is likely to be important in committee chair nomination. In post-communist Europe, the professionalization of parliamentary elites is positively correlated with the number of parliamentary terms and with the democratic development of the country (Kopecky 2001; Norton \& Olson 2007; Semenova et al. 2013). Based on these observations, we expect the effect of seniority to increase after the transition phase and gradually replace the initial importance of sector knowledge. Party leadership (H3) is an important component in the life of a political party, with functions that do not depend on democratization or parliamentary development (Cross and Pilet 2016). Accordingly, we expect its effect to be relatively steady throughout the investigated time frame. 


\section{The Romanian Parliament and its committees}

Both formal rules and the parliamentary practice indicate that parties are the main actors in the Romanian Parliament, not the committees. Since electronic records of roll-call voting were introduced in 2006, discipline seems relatively high, cohesion levels averaging more than $90 \%$ (Gherghina and Chiru 2014). In contrast, party switching was throughout the analyzed period an important phenomenon with an average percentage of 15\% MPs defecting from their original parliamentary party group (Stefan et al. 2012; Gherghina 2016). The Constitutional Court decided in 2010 (CCR 2010) that a group of independent MPs can form a parliamentary party group and have access to the associated spoils: representation in the Permanent Bureau of the Chamber, committee leadership positions proportional to their size, staff etc. 'Independent MPs' are those representatives who have renounced their party affiliation, as only one independent has ever been elected to Parliament and that happened in 1990.

Several observers noted the structural stability and gradual institutionalization of the parliamentary committee system in Romania (Chiva 2007: 205; Chiru 2010), but their powers received less attention, the sole exception being the comparative study of committees in Central and Eastern Europe by Yläoutinen and Hallerberg (2012). In order to evaluate how strong the Romanian committees are, we coded their powers and structural features as established by the Standing Orders and other legal documents. In doing so we followed the methodology proposed by André et al (2016), which itself draws heavily on Strøm (1998). Committees in the Romanian Parliament are relatively strong in their capacity to acquire information (Table 1). Thus, they can compel both ministers and civil servants to attend their sessions (art. 48-49). Each standing committee has its own staff and there has always been a high level of correspondence between their domains and the policy areas of ministers. In the last term analyzed 16 committees had policy jurisdictions that fully matched that of a single cabinet minister, while for three the match is only partial.

\section{Table 1 about here}

From 1992 to 2012, the number of standing committees has gradually increased from 14 to 19, without including in this count the joint standing committees formed with the Senate. For the computation of the corresponding score in Table 1, that takes into account the minimum and the maximum number of committees in the André et al (2016) sample of 31 parliamentary democracies we used as reference the number of committees that was in place for the longest time in the analyzed period: 17.

Unlike what Yläoutinen and Hallerberg (2008) claim, the Romanian committees do not have the right to initiate legislation. This is restricted by Constitution to the cabinet, individual MPs or 100,000 citizens (art. 75). However, the committees do enjoy substantial rewriting ability. Bills are always considered by committees prior to the plenary stage and the plenary votes on the text of the bill as amended by the committees, not separately on the initial bill and the committee amendments (art 105-107). The Permanent Bureau of the Chamber establishes

the deadlines for the standing committees to consider each bill (art. 67), thus we coded the 
control of the timetable as 0 . The committees have to submit their reports in 14-60 days or within three days when the urgency procedure is adopted (Bågenholm 2008: 93). ${ }^{1}$

The overall value of the index of committee strength is 0.73 , a score surpassed by only 4 legislatures in the sample examined by André et al (2016). It is worth noting that two of these legislatures are Eastern European (Lithuania and Estonia), while the score for Hungarian committees is only marginally smaller. As noted by André et al (2016: 5) legislatures 'in Central and Eastern Europe tend to have more extensive powers, having modeled their committee structures after the U.S. example'. This further justifies our argument that Romanian committees are illustrative for Eastern European legislatures.

The formal powers granted to committees in Romania are also matched by their actual role in the parliamentary practice. Thus, one author argues that after the 2001 constitutional revision the gravity center of the legislative process moved from the plenary sessions to committees, particularly through the substantial reduction of plenary debates (Ionescu 2011: 211-2) and the fact that the committee report recommendation (to adopt or reject the bill) now structures much more the debates ${ }^{2}$. Given this level of strength and the fact that multiparty government is the norm in Romania, which in turn creates substantial incentives for keeping tabs on government coalition partners through committee oversight (Martin and Vanberg 2011), Romanian parties should be very much interested in the allocation of committee chairs.

\section{Rules regarding committee chairs}

The Standing Orders say that the party group leaders make the nominations for the committee offices, following negotiations between the parties and that 'the bureau of the committee should respect 'as much as possible' the political configuration of the Chamber' (art. 41 of the 1994 Standing Orders). The nominations need to be approved by the majority of committee members, but these votes seem just a formality as it is the case in many other European Parliaments (Strøm 1998: 41). An MP can lose the committee office at the request of the party which proposed her or at the request of $1 / 3$ of the committee members and if the majority of the committee members vote for it. (art. 41). ${ }^{3}$

The 1994 Standing Orders also established that the committee bureau is limited to one chairman, two deputy chairmen and two secretaries. Collectively, the members of the committee bureau propose the internal functioning rules and the daily agenda, allocate tasks to the members and can create sub-committees (art. 42). The chairman leads the committee sessions, represents the committee in the relation with the leadership of the Chamber and with other committees and can invite experts, state officials or other citizens for hearings (art. 43). The chairman also proposes rapporteurs for each bill that is examined by the committee (art. 52) and summons the members for committee meetings. ${ }^{4}$ The deputy chairmen exercise the

\footnotetext{
${ }^{1}$ Since 2009, the committee chairs have the right to ask for the extension of the deadline a maximum of two times, but the final decision regarding the extension rests with the Permanent Bureau of the Chamber.

${ }^{2}$ Ionescu (2011) argues that since 2001 if the committee report recommends the rejection of the bill the debate is very short.

${ }^{3}$ In 2005 the threshold for the committee members to request the removal of a committee leader was raised to more than half of the members. However, the Constitutional Court ruled this provision unconstitutional in the same year. Currently, only the parliamentary party group that nominated the legislator can request the removal.

${ }^{4}$ During parliamentary sessions the committees convene once a week.
} 
duties of the chairman when she is absent, whereas the secretary is in charge with keeping the record regarding presence and votes as well as with drafting the committee documents (art. 4445). None of the above provisions were modified in the analyzed period.

\section{Data, measurements and method}

The hypotheses are tested using a data set that includes all 1,771 members of the Chamber of Deputies (lower chamber of the Romanian Parliament) that have served between 1992 and 2012, i.e., in the first five parliamentary terms. ${ }^{5}$ MPs that were serving as ministers were excluded for the periods in which they were part of the government. The pooled sample includes 2079 cases, because some MPs were members in more than one standing committee. Data on party affiliation, parliamentary activities and committee membership comes from Tufis (2015a, 2015b, 2015c, 2015d, 2015e) and we collected information regarding sector knowledge, past and current committee positions, the list position of the MPs and vote share. The dependent variable of this study is dichotomous: the committee members who were selected chairs are coded 1 , while all others are coded 0.

In addition to the main effects discussed above we control for several variables that could have an effect on the selection of committee chairs: electoral security, district magnitude, the number of committees in which the MP is a member, whether the MP holds a Chamber office and mandate duration. The expectations regarding electoral security are rather ambivalent. On the one hand, parties could nominate as committee chairs the most vulnerable MPs, in order to help them gather more votes. On the other hand, the partisan theory of committee organization suggests that because the costs for policy specialization are high, parties will tend to select as committee chairs those MPs who are less likely to lose their seats (Hansen 2011: 351). Under closed list PR, MPs from counties with smaller district magnitude could be more interested in constituency service than in policy issues and committee work (Carey and Shugart 1995), as long as committees are not able to allocate pork barrel projects to constituencies. ${ }^{6}$ We control for the number of committee memberships, to account for the possibility that an MP might increase her chances of being selected as a chair by serving in more committees. Mandate duration is included in the model because MPs with replacement mandates or those who resign early in the term have less of a chance to be selected as committee chairs. Rather similarly, legislators who hold a more important 'mega-seat', such as members of the Permanent Bureau of the Chamber have less time and desire to serve as committee chairs.

\section{Variable operationalization}

Sector knowledge, the first independent variable, is a cumulative index of education and expertise (field of work before getting a parliamentary seat). Each of the two was originally coded as a dummy variable in which 1 is the equivalent of a match between the committee in which the MP works and his/her education, on the one hand, and expertise, on the other hand. We focused on both education and expertise because although the two are highly correlated

\footnotetext{
5 The 1990-92 Parliament served as a Constitutional Assembly, hence we excluded it. We also excluded the MPs that represent national minorities because they ran for reserved seats and do not have a party.

${ }^{6}$ In Romania budgetary transfers and infrastructure projects are allocated exclusively at government level.
} 
there is a non-negligible MPs with a different expertise than education. The resulting index is coded on a three-point ordinal scale where 0 stands for no match between committee and either education or expertise, 1 is a match of the committee with one of the two variables, and 2 is a match of the committee with both education and expertise (for details, see Appendix 1).

Chair seniority, committee office seniority, committee seniority, and other committee office are a series of dummies. Chair seniority is coded 1 for those MPs who were chairs of the same committee in the past. Committee office seniority is coded 1 if the MP was deputy chair or secretary of the same committee in the past. Committee seniority indicates simple membership, with no office, in the same committee in the past. Ideally we would be able to use a continuous measure indicating the exact duration of membership, to distinguish between those MPs who were members of the committee for just a couple of months and those who served several terms in it. Unfortunately, such detailed data was not readily available. Finally, other committee office is coded 1 for the committee members who were chairs or deputy chairs of any committee in the previous legislative term. Legislative experience measures the years of membership in Parliament before the analyzed term in office. National party leader is a dichotomous variable in which 1 stands for a party leadership position at national level (e.g. president, vice-president, member in the national executive etc.).

In 2008, Romania shifted from a closed-list proportional representation (PR) system to an original mixed-member proportional system in which all MPs are elected from Single Member Districts (SMDs). In order to have a measure of electoral security that is comparable across the two electoral systems we use the indicator proposed by Olivella and Tavits (2014). Electoral security is computed as the difference between the party list share of mandates (for the 1992-2004 terms) or the candidate share of votes (for the 2008 term) and Lijphart's (1999) effective electoral threshold, which is $\frac{.75}{M+1}$ where $M$ is the district magnitude. The latter is measured in our analysis as the difference between the party list share of seats (for the PR terms) or the candidate share of votes (for the 2008 term) and the effective electoral threshold. The mandate duration is a count measure of the days of membership in the legislature in the analyzed term. Chamber office is a dichotomous variable where 1 stands for membership in the Permanent Bureau of the Chamber during the analyzed legislative term. The number of committee memberships counts the committees in which the committee member worked during a term, including standing, special and inquiry committees, as well as joint standing committees with the Senate (the upper Chamber of the Romanian Parliament).

Table 2 presents the descriptive statistics for the dependent variable and the covariates used in the models. One of the impressive findings is that MPs have an average score of 0.9 on the sector knowledge variable, which means that there are many legislators who have either academic training or professional expertise in the policy field of the committee they serve in.

\section{Table 2 about here}

We use the fixed effects conditional logit model (Chamberlain estimator) because it is more appropriate for the data structure and the purpose of our analysis. This is so because MPs are nested in panels (the committees) and they run in specific races for each committee chair position. The races vary both in the number of competitors, prestige of the position and in the 
characteristics of the choice alternatives (i.e. the characteristics of the MPs who could be the chairs). Thus, we compare the MPs' attributes and quality only with the other MPs who are members of the same committee and were potential candidates for the same position (Cann 2008: 277). Moreover, the binary DV makes the Chamberlain estimator the appropriate choice, since McFadden's standard conditional logit estimator was designed and is used for multiple, not dichotomous, choices or outcomes. The following section includes the multivariate statistical analyses which were ran with two purposes: to observe the effect of the hypothesized relationships across legislative terms and to identify differences in committee chair selection patterns according to committee importance, as evaluated by the legislators themselves.

\section{Assessing the effect of knowledge, experience and party credentials}

The conditional fixed effects logit models in Table 3 present the results separately for each legislative term, and the findings of the model ran on the pooled data. ${ }^{7}$ The values of the McFadden's $R^{2}$ indicate a better fit of the models for the 1992, 2000 and 2008 legislative terms compared to all other models. The odds ratios in Table 2 show that indeed sector knowledge was a crucial predictor of committee chair selection in the first terms after the transition to democracy. Indeed, in the second and third legislature analyzed MPs with sector knowledge (education and prior activity) in the committees' policy area were on average two times more likely to become chairs of that committee as opposed to the MPs without such knowledge. As expected, with the passage of time and the increased accumulation of committee level expertise this explanatory factor loses its importance. Thus, for the 2004 and 2008 terms, the coefficients of this variable fail to reach conventional levels of statistical significance and their strength is lower compared to 1996 and 2000, and quite comparable with what we observed in 1992. The non-effect of sector knowledge for the 1992 term is mostly due to the composition of Parliament after that election. The 1992 elections brought the largest turnover in the entire analyzed period with $70 \%$ of the Members of the Chamber of Deputies being elected for the first time. This made past membership in a committee and experience as committee chair much scarcer resources and probably increased their value compared to sector knowledge. Unfortunately, this interpretation cannot be fully tested given the absence of data on chair seniority for this term.

\section{Table 3 about here}

We observe that in the last two terms chair seniority becomes the most important predictor for a positive selection outcome. Thus, MPs who were chairs in the same committee in the past have an extremely high probability of being selected for the position again: their likelihood is 6.5 times higher than that of colleagues lacking such experience in 2004 and 9.6 higher in 2008. Its effect gets stronger over time, as theoretically expected. Overall, chair seniority is also the most important predictor in the pooled model. The other variables measuring committee

\footnotetext{
${ }^{7}$ We also controlled for party size, past parliamentary activity, party switching, party magnitude, age, gender and wealth (for the last two legislative terms). None of these made a substantial difference and were not included in the models.
} 
seniority and committee leadership experience are not statistically significant, although their strength varies and their effect is in the expected direction in most regressions. When it comes to the general legislative experience, there is no empirical support for the hypothesized effect $(\mathrm{H} 2 \mathrm{e})$ : the length of the parliamentary service appears to make no difference for the likelihood to occupy a committee chair position.

Legislators who had a leadership position $(\mathrm{H} 3)$ in their parties seem significantly more likely to be selected as committee chairs in each of the last three terms analyzed, as well as in the pooled sample. In the 2000-2008 terms the probability that party elites would receive the committee chair position was between 3 and 5 times higher than that of legislators who were not part of national party leadership. The results go partially against our expectation regarding the longitudinal trend: since the role and functions of party leaders did not change over time, we expected a consistent effect of this variable. However, for the first two terms the effect goes against the hypothesized relationship and changes starting 2000 when it provides empirical support to the theoretical expectation. A possible explanation might be that party leaders became more interested in committee chair positions with the passage of time, having acknowledged their importance for a future ministerial career.

In order to grasp better the magnitude of the main effects, Figure 1 below illustrates the estimated effects from the pooled model using $95 \%$ confidence intervals. ${ }^{8}$ Intervals that cross the vertical line inserted for odds ratio of 1 imply that the corresponding effects have not reached the $95 \%$ statistical significance level.

\section{Figure 1 about here}

Among the control variables, electoral security and mandate duration have no effect on committee chair selection, whereas the number of committee memberships is a significant predictor only for the first legislative term. Overall, members of the Permanent Bureau of the Chamber are almost three times less likely to serve as committee chairs, an effect which is mostly driven by the 2008 sample. Finally, district magnitude has a positive effect, mostly consistent across legislative terms, on getting a committee chair.

Chair selection in the most important committees

A relatively recent parliamentary survey (Stefan 2010) asked the MPs which are the 3 most important standing committees. The most frequently mentioned were: the budget and finance committee (29.6\%), the committee dealing with legal issues, discipline and immunities (25.3\%), the public administration and environment committee (10.4\%) and the labor and social protection committee (9.8\%). We ran the conditional logistic regression separately for these four committees and for the rest to see whether there are any important differences in the patterns of chair selection.

\section{Table 4 about here}

\footnotetext{
${ }^{8}$ The plot was created with the user written STATA command parmest (Newson 2003).
} 
The results for committee types confirm and strengthen the conclusions reached for the longitudinal analysis. The main effects (sector knowledge, chair seniority and party leadership) are present in both samples. For the most important committees, parties still put a premium on pre-existing expertise, and not on the policy specialization acquired through committee leadership. Thus, there is strong empirical support for sector knowledge (H1), policy specialization via chair seniority $(\mathrm{H} 2 \mathrm{a})$, while party leadership also matters greatly $(\mathrm{H} 3)$. With respect to the latter, its effect is on a par with that of sector knowledge for the most salient committees and it is much stronger for the rest. Similarly, sector knowledge matters more than chair seniority for the most important committees, while the reverse is true for the rest of the committees. For the latter, a longer parliamentary career is also a significant asset.

This goes in line with our theoretical and empirical argument according to which political parties employ an institutional perspective, rather than a distributive one, in nominating committee chairs. When selecting politicians for this position, parties are likely to choose those with knowledge and sector expertise that will boost their image and arguably help achieve partisan goals (e.g. shape policy, keep tabs on ministers etc.). Moreover, visibility is higher in the important committees compared to the less important ones. With the partial exception of district magnitude none of the control variables make a difference for the selection of chairs in either type of committee. Figure 2 below illustrates comparatively the magnitude of these effects for the two types of committees.

\section{Figure 2 about here}

\section{Conclusion}

This article analyzed the determinants of committee chair nomination under specific informational and organizational constraints in a young European democracy. To this end, it tested the explanatory power of the MPs' sector knowledge, legislative experience and party credentials using a longitudinal dataset that allows to assess variation over time. The main findings indicate that sector knowledge is of great importance in the first parliamentary terms and overall in committees of high importance. Specialized legislative experience (i.e. chair seniority) becomes more prominent as time passes and the same is true for party leaders. The explanatory power of these three features weigh considerably more than any other factors analyzed.

The implications of this single case study reach beyond its context and have broad importance for the study of parliamentary committees. At theoretical level, we propose a model that applies to contexts in which legislators face high informational and organizational constraints. Our contribution to the existing literature is the identification of particular conditions under which expertise and political experience play a role in the legislative career. At the same time, the analytical model has a longitudinal component which illustrates that effects are likely to change over time. Such an analytical framework could travel to other countries facing regime change and transition towards democracy, but would also represent a valid point of reference in future comparisons with established democracies. Regarding the latter, their longitudinal variation may not be due to transition challenges but rather to dramatic changes in the structure of parliament composition (e.g. the access of new parties, change of electoral system). At empirical level, previous research linked parliamentary professionalization to re- 
election rates and the accumulation of local and party experience. This analysis went one step further and analyzed how party related mechanisms may influence policy specialization. It revealed that policy specialization is indeed a criterion for committee chair selection after the initial institutionalization of the Parliament is achieved and professionalization becomes the new target. These two types of contributions add to the comparative literature and set the grounds for further research. One of the immediate directions is a cross-national test that would include several new and established European democracies. Such a test could offer further insights regarding the explanatory potential of the framework, particularly when faced with different party characteristics and legislative features. 


\begin{tabular}{|c|c|}
\hline Variable & Operationalization \\
\hline Chair & $0=$ no; $1=$ yes \\
\hline Sector knowledge & $\begin{array}{l}0=\text { none; } 1 \text { = the } \mathrm{MP} \text { has either academic training or a } \\
\text { professional career in the committee's policy area; } 2=\text { the MP } \\
\text { has both academic training and a professional career in the } \\
\text { committee's policy area. }\end{array}$ \\
\hline Chair seniority & $\begin{array}{l}0=\text { the MP was not a chair in the same committee in previous } \\
\text { legislative terms; } 1 \text { = the MP chair of the same committee in } \\
\text { previous legislative terms. }\end{array}$ \\
\hline $\begin{array}{l}\text { Committee office } \\
\text { seniority }\end{array}$ & $\begin{array}{l}0=\text { the MP was not secretary or deputy chair in the same } \\
\text { committee in previous legislative terms; } 1=\text { the MP secretary } \\
\text { or deputy chair of the same committee in previous legislative } \\
\text { terms. }\end{array}$ \\
\hline Committee seniority & $\begin{array}{l}0=\text { the MP was not a member of the same committee in } \\
\text { previous legislative terms; } 1=\text { the MP was a member of the } \\
\text { same committee in previous legislative terms. }\end{array}$ \\
\hline Other committee office & $\begin{array}{l}0=\text { the MP had no committee office in the previous term; } 1= \\
\text { the MP was committee chair or vice-chair in the previous } \\
\text { legislative term. }\end{array}$ \\
\hline $\begin{array}{l}\text { Length of } \\
\text { parliamentary career }\end{array}$ & $\begin{array}{l}\text { Years of membership in Parliament before the election in the } \\
\text { current term. }\end{array}$ \\
\hline National party office & $\begin{array}{l}0=\text { no national party office; } 1=\text { The MP had a party leadership } \\
\text { position at national level prior to his election in that term. }\end{array}$ \\
\hline Electoral security & $\begin{array}{l}\text { The difference between the party list share of seats (for the } \\
\text { PR terms) or the candidate share of votes (for the } 2008 \text { term) } \\
\text { and the effective electoral threshold. }\end{array}$ \\
\hline District magnitude & $\begin{array}{l}\text { Natural logarithm of the district magnitude. For the } 2008 \\
\text { elections we used the natural logarithm of the number of } \\
\text { SMDs in the constituency (i.e. county). }\end{array}$ \\
\hline Mandate duration & Days of membership in the Parliament in the analyzed term. \\
\hline Chamber office & $\begin{array}{l}0=\text { no office; } 1=\text { The MP was a member of the Permanent } \\
\text { Bureau of the Chamber during the analyzed period. }\end{array}$ \\
\hline $\begin{array}{l}\text { Number of committee } \\
\text { memberships }\end{array}$ & $\begin{array}{l}\text { Number of committee the MP was member of during the } \\
\text { term (including standing, special, inquiry committees, and } \\
\text { joint standing committees with the Senate). }\end{array}$ \\
\hline
\end{tabular}




\section{List of References:}

André, A., Depauw, S., \& Martin, S. (2015). "Trust Is Good, Control Is Better" Multiparty Government and Legislative Organization. Political Research Quarterly, 69(1), 108-120.

Bågenholm, A. (2008). Understanding Governmental Legislative Capacity. Harmonization of EU legislation in Lithuania and Romania, PhD Dissertation, University of Gothenburg.

Cann, D. M. (2008). Modeling committee chair selection in the US House of Representatives. Political Analysis, 16(3), 274-289.

Carey, J. M., \& Shugart, M. S. (1995). Incentives to cultivate a personal vote: A rank ordering of electoral formulas. Electoral studies, 14(4), 417-439.

Carroll, R., \& Cox, G. W. (2012). "Shadowing Ministers: Monitoring Partners in Coalition Governments. Comparative Political Studies 45(2), 220-36.

Chiru, M. (2010). 'Turnover and Legislative Institutionalization in Romania, Hungary and Estonia', paper prepared for the workshop Twenty Years After. Parliamentary Democracy and Parliamentary Representation in Post-Communist Europe, Jena, May 7-8.

Chiva, C. (2007). The institutionalisation of post-Communist parliaments: Hungary and Romania in comparative perspective. Parliamentary Affairs,60(2), 187-211.

Ciftci, S., Forrest, W., \& Tekin, Y. (2008). Committee assignments in a nascent party system: The case of the Turkish Grand National Assembly. International Political Science Review, 29(3), 303-324.

Cox, G. and McCubbins, M.D. (1993) Legislative Leviathan: Party Government in the House. Berkeley: University of California Press

Cox, G. and McCubbins, M.D. (2005). Setting the Agenda: Responsible Party Government in the US House of Representatives. Cambridge: Cambridge University Press.

Cross, W. \& Pilet, J.-B. eds., 2016. The Politics of Party Leadership: A Cross-National Perspective, Oxford: Oxford University Press.

Deering, C. J., \& Wahlbeck, P. J. (2006). US House Committee Chair Selection Republicans Play Musical Chairs in the 107th Congress. American Politics Research, 34(2), 223-242.

De Winter, L. (1991) 'Parliamentary and Party Pathways to the Cabinet', in Blondel, J. \& Thiébault, J-L. (eds.) The Profession of Government Minister in Western Europe, London: Macmillan, pp. 44-69.

Dowding, K. \& Dumont, P. (2009) Structural and Strategic Factors Affecting the Hiring and Firing of Ministers', in Dowding, K. \& Dumont, P. (eds.) The Selection of Ministers in Europe; Hiring and Firing, London: Routledge, pp. 1-20

Gherghina, S. (2014) Party Organization and Electoral Volatility in Central and Eastern Europe: Enhancing Voter Loyalty. London: Routledge.

Gherghina, S. (2016) 'Rewarding the "traitors"? Legislative defection and re-election in Romania', Party Politics, 22(4), pp. 490-500.

Gherghina, S. and Chiru, M., 2013. Taking the short route: Political parties, funding regulations, and state resources in Romania. East European Politics and Societies, 27(1), pp.108-128.

Gherghina, S., \& Chiru, M. (2014). 'Determinants of Legislative Voting Loyalty under Different Electoral Systems: Evidence from Romania', International Political Science Review, 35(5), pp. 523-541.

Groseclose, T. and King, D. (2001). Committee Theories Reconsidered, in Dodd, L. C. and Oppenheimer, B. I. (eds.), Congress Reconsidered, $7^{\text {th }}$ ed. Washington DC: CQ Press. 
Hansen, M. E. (2011). A random process? Committee assignments in Dáil Éireann. Irish Political Studies, 26(3), 345-360.

Heller, W. B. \& Mershon, C., eds. (2009). Political Parties and Legislative Party Switching, New York: Palgrave Macmillan.

Ilonszki, G. (1995). 'Institutionalization and Professionalization in the First Parliament' in Agh, A. \& Kurtan, S. (eds.), Democratization and Europeanization in Hungary: The First Parliament (1990-1994), Budapest: Hungarian Center for Democracy Studies.

Ionescu, I. N. (2011). Le Rôle du Parlement dans la creation des politiques publiques en Roumanie postcommuniste. Iasi: Institutul European.

Kopecky, P. (2001). Parliaments in the Czech and Slovak Republics: Party Competition and Parliamentary Institutionalization, Aldershot: Ashgate.

Krehbiel, K. (1992). Information and Legislative Organization. Michigan: University of Michigan Press.

Lijphart, A. (1999). Patterns of Democracy, New Haven, Conn.: Yale University Press.

Mansfeldova, Z., Olson, D. M., \& Rakusanova, P. (eds.) (2004). Central European Parliaments. First Decade of Democratic Experience and Future Prospective, Prague: Institute of Sociology, Academy of Science of the Czech Republic.

Martin, L. W., \& G. Vanberg. (2011). Parliaments and Coalitions: The Role of Legislative Institutions in Multiparty Governance. Oxford: Oxford University Press.

Martin, S. (2014). Why electoral systems don't always matter The impact of 'mega-seats' on legislative behaviour in Ireland. Party Politics, 20(3), 467-479.

Mattson, I. \& Strøm, K. (1995). Parliamentary Committees. in Döring, H. (ed.) Parliaments and majority rule in Western Europe, Mannheim: MZES, 249-307.

McFadden, D. (1974). Conditional logit analysis of qualitative choice behavior. In Zarembka, P. (ed.) Frontiers in econometrics, New York: Academic Press, 105-42.

McElroy, G. (2006). Committee Representation in the European Parliament. European Union Politics, 7(1), 5-29.

Newson, R. 2003. 'Confidence intervals and p-values for delivery to the end user', The Stata Journal 3(3): 245-269.

Norton, P. \& Olson, D. M. (2007). 'Post-Communist and Post-Soviet Legislatures: Beyond Transition', The Journal of Legislative Studies, 13(1), 1-11.

Olivella, S., and Tavits, M. 2014. 'Legislative Effects of Electoral Mandates', British Journal of Political Science, 44(2): 301-321.

Olson, D. M., \& Crowther, W. E. (2002). Committees in Post-Communist Democratic Parliaments, Ohio: Ohio State University Press.

Ostrow, J. M. (2002). Comparing post-Soviet Legislatures: a theory of institutional design and political conflict, Ohio: Ohio State University Press.

Roper, S. D. \& Crowther, W. (1998). 'The Institutionalization of the Romanian Parliament: A Case Study of the State-Building Process in Eastern Europe', Southeastern Political Review, 26(2), 401-426.

Santos, F., \& Renno, L. (2004). The selection of committee leadership in the Brazilian Chamber of Deputies. The journal of legislative studies, 10(1), 50-70.

Semenova, E., Edinger, M. \& Best, H. (eds.). (2013). Parliamentary Elites in Central and Eastern Europe: Recruitment and Representation (Vol. 3). Routledge, New York. 
Stefan, L. (2010) Survey of the Romanian Chamber of Deputies. Machine readable data files.

Stefan, L., Gherghina, S., \& Chiru, M. (2012). We all agree that we disagree too much: attitudes of Romanian MPs towards party discipline. East European Politics, 28(2), 180-192.

Strøm, K. (1998) Parliamentary committees in European democracies, The Journal of Legislative Studies, (4)1, 21-59.

Tufis, C. D. (2015a). "Studii Electorale Românești: Parlamentari Români 1992-1996 (SER-PROM1992)", FSPUB / IDC / RQSA, București, Versiunea 1.0,doi: 10.13140/RG.2.1.2115.8569

Tufis, C. D. (2015b). "Studii Electorale Românești: Parlamentari Români 1996-2000 (SER-PROM1996)", FSPUB / IDC / RQSA, București, Versiunea 1.0, DOI: 10.13140/RG.2.1.2720.0169

Tufis, C. D. (2015c). "Studii Electorale Românești: Parlamentari Români 2000-2004 (SER-PROM2000)", FSPUB / IDC / RQSA, București, Versiunea 1.0, DOI: 10.13140/RG.2.1.1221.1361

Tufis, C. D. (2015d). "Studii Electorale Românești: Parlamentari Români 2004-2008 (SER-PROM2004)", FSPUB / IDC / RQSA, București, Versiunea 1.0, DOI: 10.13140/RG.2.1.4095.4726

Tufis, C. D. (2015e). "Studii Electorale Românești: Parlamentari Români 2008-2012 (SER-PROM2008)", FSPUB / IDC / RQSA, București, Versiunea 1.0, DOI: 10.13140/RG.2.1.1364.6566

Weingast, B. and Marshall, W. (1988). The Industrial Organization of Congress; or, Why Legislatures, like Firms, are not Organized as Markets, Journal of Political Economy 96(1): 132-63.

Yläoutinen, S., \& Hallerberg, M. (2008). The role of parliamentary committees in the budgetary process in the Central and Eastern European countries. In S. Ganghof, C. Hönnige, \& C. Stecker (Eds.), Parlamente, Agendasetzung und Vetospieler: Festschrift für Herbert Döring (pp. 147-174). Wiesbaden, Germany: VS Verlag.

Yordanova, N. (2009). The Rationale behind Committee Assignment in the European Parliament. Distributive, Informational and Partisan Perspectives. European Union Politics, 10(2), 253-280.

*** Resolution no. 8/ 1994 approving the Standing Orders of the Chamber of Deputies, available at: http://legislatie.just.ro/Public/DetaliiDocument/3850?isFormaDeBaza=True\&rep=True

*** CCR (2010) The Constitutional Court of Romania. Decision no. 1611, available at: http://legislatie.just.ro/Public/DetaliiDocument/124662 
Table 1: The Powers of Parliamentary Committees in Romania

\begin{tabular}{ll}
\hline Dimension & Score \\
\hline Information acquisition & .67 \\
Number & .9 \\
Correspondence & 1 \\
Minister & 1 \\
Civil servants & 1 \\
Staff & \\
Rewrite authority & 0 \\
Initiate & 1 \\
Rewrite & 1 \\
Stage & \\
Control of the committee timetable & 0 \\
Timetable & 0.73 \\
Index of committee strength & \\
\hline
\end{tabular}


Table 2: Descriptive statistics of dependent variable and covariates (1992-2012)

\begin{tabular}{l|c|rrrr|c}
\hline Variable types & Variables & Mean & Std. dev & Min. & Max. & N \\
\hline DV & Chair or deputy chair & 0.05 & 0.22 & 0.00 & 1.00 & 2079 \\
\hline Expertise & Sector knowledge & 0.90 & 0.92 & 0.00 & 2.00 & 2079 \\
\hline \multirow{3}{*}{ Legislative } & Chair seniority & 0.02 & 0.12 & 0.00 & 1.00 & 2079 \\
experience & Committee seniority & 0.13 & 0.34 & 0.00 & 1.00 & 2079 \\
& Committee office seniority & 0.05 & 0.21 & 0.00 & 1.00 & 2079 \\
& Other committee office & 0.05 & 0.22 & 0.00 & 1.00 & 2079 \\
& Length of parl. career & 1.81 & 3.11 & 0.00 & 18.08 & 2079 \\
\hline Party influence & National leader & 0.26 & 0.44 & 0.00 & 1.00 & 2079 \\
\hline \multirow{4}{*}{ Controls } & Electoral security & 0.20 & 0.19 & -0.36 & 0.88 & 2079 \\
& Chamber office & 0.06 & 0.24 & 0.00 & 1.00 & 2079 \\
& No. committee mbs. & 1.88 & 1.05 & 1.00 & 7.00 & 2079 \\
& Mandate duration & 1366.91 & 298.65 & 17.00 & 1488.00 & 2079 \\
& District magnitude & 2.13 & 0.49 & 1.10 & 3.37 & 2079 \\
\hline
\end{tabular}


Table 3: Determinants of committee chair selection per legislative term

\begin{tabular}{|c|c|c|c|c|c|c|}
\hline & Pooled & 2008 & 2004 & 2000 & 1996 & $1992^{9}$ \\
\hline \multirow[t]{2}{*}{ Sector knowledge } & $1.67 * * *$ & 1.46 & 1.37 & $2.30 * *$ & $1.94^{*}$ & 1.38 \\
\hline & $(0.23)$ & $(0.46$ & $(0.40)$ & $(0.94)$ & $(0.67$ & $(0.50)$ \\
\hline \multirow[t]{2}{*}{ Chair seniority } & $6.26 * * *$ & $9.65^{* *}$ & $6.47^{*}$ & 12.75 & 3.44 & \\
\hline & (3.53) & (9.31) & (7.14) & $(25.23)$ & (6.77) & \\
\hline \multirow[t]{2}{*}{ Committee seniority } & 1.16 & 1.01 & 1.93 & 0.48 & 0.22 & 2075.68 \\
\hline & (0.39) & (0.69) & $(1.26)$ & $(0.59)$ & $(0.21)$ & $(20339.89)$ \\
\hline \multirow[t]{2}{*}{ Committee office seniority } & 1.41 & 0.55 & 1.83 & 2.63 & 1.12 & \\
\hline & $(0.64)$ & $(0.56)$ & $(1.73)$ & $(2.68)$ & $(1.27)$ & \\
\hline \multirow[t]{2}{*}{ Other committee office } & 1.24 & 1.35 & 0.67 & 0.95 & 0.53 & \\
\hline & $(0.51)$ & $(0.92)$ & $(0.60)$ & $(1.12)$ & $(0.73)$ & \\
\hline \multirow[t]{2}{*}{ National leader } & $2.37 * * *$ & $3.06 * *$ & $3.52 * *$ & $5.17 * * *$ & 0.82 & 0.31 \\
\hline & $(0.53)$ & $(1.45)$ & $(1.82)$ & $(3.00)$ & $(0.53)$ & $(0.28)$ \\
\hline \multirow[t]{2}{*}{ Length of parl. career } & 1.05 & 1.08 & 1.00 & 1.01 & 1.22 & 0.03 \\
\hline & $(0.04)$ & $(0.06)$ & $(0.08)$ & $(0.12)$ & $(0.18)$ & $(0.17)$ \\
\hline \multirow[t]{2}{*}{ Electoral security } & 1.22 & 18.28 & 4.48 & 3.72 & 0.08 & 0.16 \\
\hline & $(0.71)$ & (34.33) & $(6.86)$ & $(4.97)$ & $(0.14)$ & $(0.31)$ \\
\hline \multirow[t]{2}{*}{ Chamber office } & $0.37^{*}$ & $0.05^{* *}$ & 1.29 & 0.00 & 0.00 & 0.00 \\
\hline & (0.19) & $(0.06)$ & $(0.87)$ & $(0.00)$ & $(0.00)$ & $(0.00)$ \\
\hline \multirow[t]{2}{*}{ No. comm. membership } & 1.00 & 0.75 & 1.07 & 0.87 & 0.92 & $2.37 * *$ \\
\hline & $(0.11)$ & $(0.15)$ & $(0.25)$ & $(0.29)$ & $(0.36)$ & $(1.01)$ \\
\hline \multirow[t]{2}{*}{ Mandate duration } & $1.00 *$ & 1.00 & 1.00 & 1.01 & 1.13 & 1.00 \\
\hline & $(0.00)$ & $(0.00)$ & $(0.00)$ & $(0.02)$ & $(18.48)$ & $(0.00)$ \\
\hline \multirow[t]{2}{*}{ District magnitude } & $1.59 * *$ & 1.69 & 1.55 & 0.90 & 1.13 & $3.46^{* *}$ \\
\hline & $(0.31)$ & $(0.76)$ & $(0.63)$ & $(0.45)$ & $(0.61)$ & $(1.92)$ \\
\hline $\mathrm{N}$ & 2079 & 462 & 423 & 348 & 361 & 338 \\
\hline McFadden's $\mathrm{R}^{2}$ & 0.12 & 0.26 & 0.16 & 0.29 & 0.17 & 0.29 \\
\hline
\end{tabular}

Notes: Significance at $* p<0.10, * * p<0.05, * * * p<0.01$.

Cell entries are odds ratios. Standard errors in parentheses

${ }^{9}$ For this model data on 'Office seniority' and 'Past committee office' are missing because we did not have information on the MPs' committee positions in the previous term - we knew only their membership. 
Table 4: Determinants of chair selection by committee importance (1992-2012)

\begin{tabular}{|c|c|c|}
\hline & $\begin{array}{l}\text { Most important } \\
\text { committees }\end{array}$ & $\begin{array}{l}\text { Other } \\
\text { committees }\end{array}$ \\
\hline \multirow[t]{2}{*}{ Sector knowledge } & $2.36 * * *$ & $1.39 *$ \\
\hline & $(0.62)$ & $(0.23)$ \\
\hline \multirow[t]{2}{*}{ Chair seniority } & 3.44 & $10.38^{* * *}$ \\
\hline & (5.14) & (6.75) \\
\hline \multirow[t]{2}{*}{ Committee seniority } & 1.38 & 1.21 \\
\hline & $(0.86)$ & $(0.48)$ \\
\hline \multirow[t]{2}{*}{ Committee office seniority } & 1.96 & 1.67 \\
\hline & $(1.92)$ & (0.89) \\
\hline \multirow[t]{2}{*}{ Other committee office } & 0.94 & 1.11 \\
\hline & $(0.88)$ & $(0.55)$ \\
\hline \multirow[t]{2}{*}{ National leader } & $2.20 *$ & $2.54 * * *$ \\
\hline & $(0.90)$ & (0.69) \\
\hline \multirow[t]{2}{*}{ Length of parl. career } & 0.95 & $1.08 *$ \\
\hline & (0.09) & $(0.04)$ \\
\hline \multirow[t]{2}{*}{ Electoral security } & 0.91 & 1.28 \\
\hline & $(0.97)$ & $(0.90)$ \\
\hline \multirow[t]{2}{*}{ Chamber office } & 0.32 & 0.47 \\
\hline & $(0.35)$ & $(0.28)$ \\
\hline \multirow[t]{2}{*}{ No. comm. membership } & 0.92 & 1.07 \\
\hline & $(0.20)$ & $(0.14)$ \\
\hline \multirow[t]{2}{*}{ Mandate duration } & 1.00 & 1.00 \\
\hline & $(0.00)$ & $(0.00)$ \\
\hline \multirow[t]{2}{*}{ District magnitude } & $2.13 * *$ & 1.32 \\
\hline & $(0.73)$ & $(0.32)$ \\
\hline $\mathrm{N}$ & 593 & 1486 \\
\hline McFadden's $\mathrm{R}^{2}$ & 0.14 & 0.14 \\
\hline
\end{tabular}

Notes:Significance at $* p<0.10, * * p<0.05,{ }^{* * *} p<0.01$

Cell entries are odds ratios.Standard errors in parentheses 
Figure 1: Estimated effects with $95 \%$ confidence intervals based on the pooled model

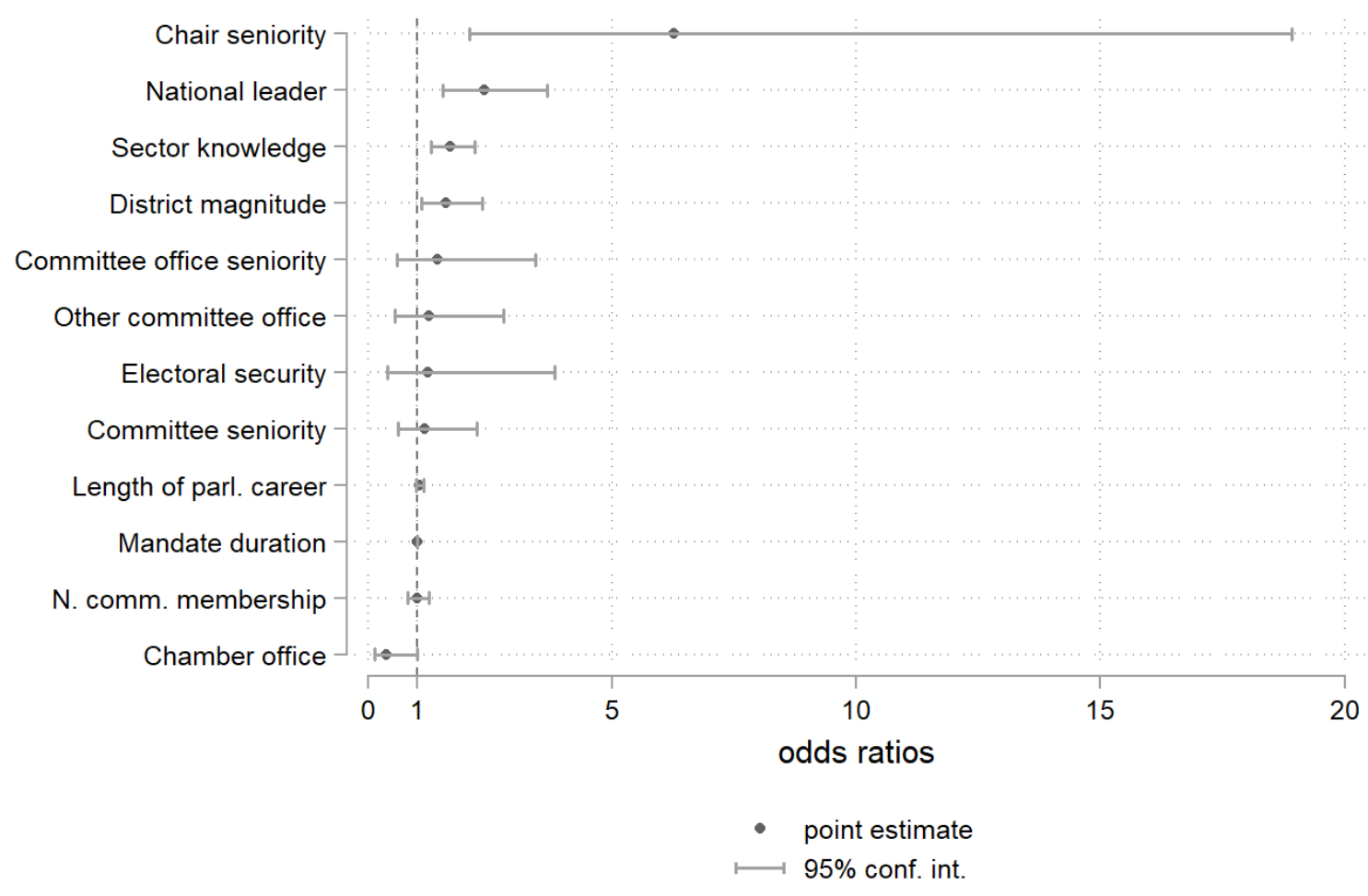


Figure 2: Estimated effects with $95 \%$ confidence intervals for the two types of committees
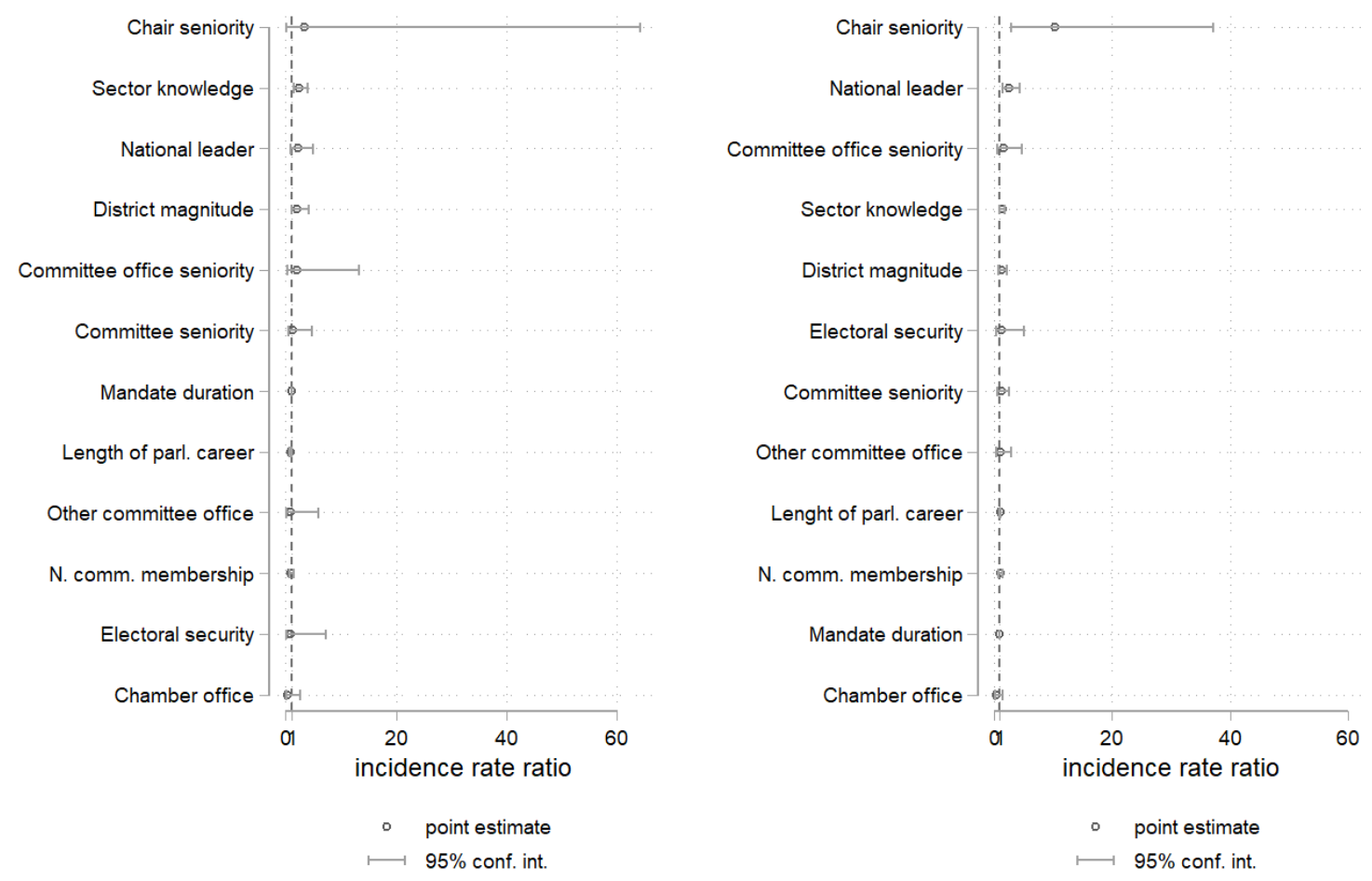